\title{
PENGARUH PEMBERDAYAAN LEMBAGA PERKREDITAN DAN SUMBER PENDANAAN TERHADAP MANAJEMEN STRATEGI USAHA MIKRO KECIL MENENGAH (UMKM) DI KOTA BANDAR LAMPUNG
}

\author{
A Putra Ridwan $\mathrm{S}^{1}$ Agus Purnomo ${ }^{2}$ \\ ${ }^{1}$ Fakultas Ilmu Sosial dan Ilmu Politik, Universitas Bandar Lampung \\ J1. Zainal Abidin Pagar Alam No.26, Labuhan Ratu, Kedaton, 35142, \\ Bandar Lampung, Indonesia \\ E-mail: \\ a_putra.16411059@student.ubl.ac.id \\ agus.purnomo@ubl.ac.id
}

\begin{abstract}
ABSTRAK
Usaha Kecil Mikro dan Menengah (UMKM) mempunyai peran yang strategis dalam pembangunan ekonomi nasional, yaitu berperan dalam pertumbuhan ekonomi dan juga berperan dalam pendistribusian hasil-hasil pembangunan. Penelitian ini dilakukan dengan tujuan mengetahui pengaruh pemberdayaan lembaga perkreditan dan sumber pendanaan terhadap manajemen strategi Usaha Mikro Kecil Menengah (UMKM) di Kota Bandar Lampung. Penelitian ini termasuk ke dalam penelitian kuantitatif. Populasi penelitian ini adalah semua pelaku UMKM di Kota Bandar Lampung sebanyak 3.543 UMKM dan jumlah sampel sebanyak 97 UMKM. Analisis dalam penelitian ini menggunakan analisis regresi linier berganda. Hasil penelitian menunjukkan hasil uji $t_{\text {hitung }}$ untuk variabel pemberdayaan lembaga perkreditan sebesar $15,472\left(t_{\text {hitung }}=15,472>t_{\text {tabel }}=1,974\right)$ yang berarti bahwa ada pengaruh pemberdayaan lembaga perkreditan terhadap manajemen strategi Usaha Mikro Kecil Menengah (UMKM) di Kota Bandar Lampung. Hasil uji thitung untuk variabel sumber pendanaan sebesar 5,469 $\left(t_{\text {hitung }}=5,469>t_{\text {tabel }}=1,974\right)$ yang berarti bahwa ada pengaruh sumber pendanaan terhadap manajemen strategi Usaha Mikro Kecil Menengah (UMKM) di Kota Bandar Lampung. Berdasarkan hasil uji $\mathrm{F}$ di atas, diperoleh $\mathrm{F}_{\text {hitung }}=73,246$ $>\mathrm{F}_{\text {tabel }}=3,05$ dengan signifikansi sebesar 0,014 $(<\alpha=0,05)$ yang berarti bahwa ada pengaruh pemberdayaan lembaga perkreditan dan sumber pendanaan terhadap manajemen strategi Usaha Mikro Kecil Menengah (UMKM) di Kota Bandar Lampung.

Kata Kunci: Pemberdayaan Lembaga Perkreditan, Sumber Pendanaan, Manajemen Strategi, Usaha Mikro Kecil Menengah (UMKM)
\end{abstract}

\section{PENDAHULUAN}

Pertumbuhan Usaha Mikro kecil dan Menengah setiap tahun mengalami peningkatan, dimana jumlah UMKM di Indonesia pada tahun 2019 sebanyak 48,9 juta unit, dan terbukti memberikan kontribusi 53,28\% terhadap PDB (Pendapatan Domestik Bruto) dan 96,18\% terhadap penyerapan tenaga kerja. Selain itu, selama 2016-2019, laju pertumbuhan PDB UMKM dengan minyak dan gas (Migas) dan tanpa migas ternyata tidak berbeda jauh, hanya pada PDB tanpa migas agak tertarik ke atas. Sementara itu, kemajuan yang dicapai dalam restrukturisasi di sektor keuangan, khususnya industri perbankan, telah pula mampu menyediakan kebutuhan pembiayaan dengan tingkat pertumbuhan dan porsi yang lebih besar untuk UMKM. Perkembangan inilah yang menjadi pendorong bagi peningkatan pertumbuhan dan peran sektor UMKM dalam perekonomian nasional (Badan Pusat Statistik, 2019). 
Tabel 1. Kontribusi UMKM Terhadap Product Domestic Bruto (PDB) di Indonesia Tahun 2019

\begin{tabular}{|c|l|c|}
\hline No. & \multicolumn{1}{|c|}{ Sub Sektor UMKM } & Kontribusi terhadap PDB (\%) \\
\hline 1 & Sektor Kuliner & $32,5 \%$ \\
\hline 2 & Sektor Fashion & $28,3 \%$ \\
\hline 3 & Sektor Kerajinan & $14,4 \%$ \\
\hline 4 & Lainnya & $24,8 \%$ \\
\hline \multicolumn{2}{|c|}{ Total } & $\mathbf{1 0 0 \%}$ \\
\hline
\end{tabular}

Sumber : CNN Indonesia (2019)

Namun, berdasarkan data dari BPS (2019), jumlah pemain bisnis kuliner di Indonesia meningkat setiap tahunnya, namun pertumbuhannya selalu menurun. Pertumbuhan terbesar yaitu sebesar 27,7\% di tahun 2018, kemudian melambat hingga 2,07\% di tahun 2019. Oleh karena itu, sebuah UMKM harus memiliki keunggulan bersaing (competitive advantage) agar dapat terus bertahan dan berkembang di tengah arus globalisasi. Peran dan pertumbuhan sektor UMKM di dalam perekonomian nasional harus terus ditingkatkan, tidak saja karena ketangguhannya dalam menghadapi berbagai kejutan ekonomi tetapi juga kemampuannya yang lebih besar dalam menyediakan lapangan kerja dan mengatasi masalah kemiskinan. Apalagi dengan komitmen dan strategi yang lebih kuat dari Pemerintah yang baru, iklim investasi dan kegairahan usaha dalam perekonomian nasional, termasuk sektor UMKM akan jauh lebih baik. Untuk menjamin optimisme perkembangan UMKM di masa depan, jelas memerlukan penguatan peran dan strategi pembiayaan, khususnya dari industri perbankan untuk mendukungnya.

Strategi pengembangan pembiayaan dan pemberdayaan UMKM diperlukan dalam menghadapi berbagai masalah dalam mengembangkan UMKM, diperlukan. Terdapat beberapa alasan mengapa UMKM perlu diberdayakan. Pertama adalah karena terdapat $92 \%$ UMKM yang belum akses dengan sumber permodalan. Alasan kedua adalah karena jumlahnya sangat besar. Menurut BPS (2019), jika pengusaha UMKM tidak diberdayakan menyebabkan kemiskinan makin besar dan menjadi beban seluruh bangsa. Alasan ketiga jika UMKM diberdayakan secara tepat akan menjadi usaha kecil yang kemudian berkembang menjadi usaha menengah dan alasan keempat.

Menurut hasil penelitian Syukur (2016), umumnya usaha mikro yang mendapat pelayanan keuangan pendapatannya meningkat per bulan rata-rata $87,34 \%$ dan alasan yang kelima faktor pendanaan menjadi daya dorong bagi usaha mikro untuk naik kelas menjadi usaha kecil dan bahkan bukannya tidak mungkin untuk terus ke usaha menengah. Usaha mikro mempunyai potensi untuk dikembangkan secara cepat.

UMKM menjadi salah satu penopang pertumbuhan ekonomi, tak terkecuali di Kota Bandar Lampung, jumlah usaha mikro ini dapat dijelaskan sebagai berikut

Tabel 2. Jumlah UMKM di Kota Bandar Lampung

\begin{tabular}{|c|c|c|}
\hline No. & Tahun & Jumlah (unit) \\
\hline 1 & 2018 & 46.324 \\
\hline 2 & 2019 & 65.229 \\
\hline 3 & 2020 & 56.821 \\
\hline & Total & $\mathbf{1 6 8 . 3 7 4}$ \\
\hline
\end{tabular}

Sumber : Lakip Diskoperindag Kota Bandar Lampung (2020)

Berdasarkan Tabel 1.2 Jumlah UMKM tahun 2018 sebanyak 46.324 UMKM, sedangkan pada tahun 2019 terjadi peningkatan hingga menjadi 65.229 UMKM dan tahun 2020 terjadi 
penurunan menjadi 56.821 UKM, penurunan ini salah satunya akibat adanya pandemi Covid 19 yang melanda Indonesia. Hal ini karena sektor formal belum mampu menyerap seluruh angkatan kerja di Kota Bandar Lampung dan secara otomatis menciptakan lapangan kerja baru bagi pemain-pemain bisnis di sektor informal (Lakip Diskoperindag Kota Bandar Lampung Tahun 2019).

Berdasarkan hasil pra survei yang dilakukan peneliti pada beberapa UMKM di Bandar Lampung diperoleh keterangan bahwa kinerja UMKM masih rendah hal ini terlihat dari ratarata penghasilan perbulannya pemilik UMKM yang belum sesuai dengan harapan. Hasil wawancara yang dilakukan didapatkan informasi bahwa beberapa faktor yang mempengaruhi masih rendahnya kinerja UMKM adalah kompetensi sumber daya manusia yang tidak sesuai dengan kemampuan, sumber pendanaan yang kurang baik seperti lingkungan yang kurang strategis dan kurang mendukung serta modal finansial yang terbatas yaitu dengan modal < Rp 10.000.000.

Rumusan masalah dalam penelitian ini adalah

a. Apakah ada pengaruh pemberdayaan lembaga perkreditan terhadap manajemen strategi Usaha Mikro Kecil Menengah (UMKM) di Kota Bandar Lampung?

b. Apakah ada pengaruh sumber pendanaan terhadap manajemen strategi Usaha Mikro Kecil Menengah (UMKM) di Kota Bandar Lampung?

c. Apakah ada pengaruh pemberdayaan lembaga perkreditan dan sumber pendanaan terhadap manajemen strategi Usaha Mikro Kecil Menengah (UMKM) di Kota Bandar Lampung?

Berkaitan dengan masalah yang disebutkan di atas, maka tujuan dari penelitian ini adalah sebagai berikut:

a. Untuk mengetahui pengaruh pemberdayaan lembaga perkreditan terhadap manajemen strategi Usaha Mikro Kecil Menengah (UMKM) di Kota Bandar Lampung.

b. Untuk mengetahui pengaruh sumber pendanaan terhadap manajemen strategi Usaha Mikro Kecil Menengah (UMKM) di Kota Bandar Lampung.

c. Untuk mengetahui pengaruh pemberdayaan lembaga perkreditan dan sumber pendanaan terhadap manajemen strategi Usaha Mikro Kecil Menengah (UMKM) di Kota Bandar Lampung.

\section{TINJAUAN PUSTAKA}

Untuk menuju Negara maju, pembangunan ekonomi wajib dilakukan, pembangunan ekonomi sendiri berarti adalah suatu proses kenaikan pendapatan total dan pendapatan perkapita dengan memperhitungkan adanya pertambahan penduduk dan disertai dengan perubahan fundamental dalam struktur ekonomi suatu negara dan pemerataan pendapatan bagi penduduk suatu negara (Anggraeni, 2010). Dalam teori pembangunan ekonomi maupun pertumbuhan ekonomi, ada unsur-unsur penentu yang mendukung terjadinya pembangunan perekonomian.

Kinerja merupakan capain yang diperoleh sebuah seseorang, ataupun perusahaan dalam mencapai suatu tujuan. Kinerja yang maksimal merupakan harapan utama sebuah unit bisnis dalam menjalankan usahanya. Mulyadi (2007) menyatakan bahwa "Kinerja adalah keberhasilan personel, tim, atau unit organisasi dalam mewujudkan sasaran strategik yang telah ditetapkan sebelumnya dengan perilaku yang diharapkan". Kinerja juga merupakan sebuah gambaran atau kondisi mengenai pencapaian pelaksanaan suatu kegiatan/program/kebijaksanaan dalam mewujudkan sasaran, tujuan, misi, dan visi 
organisasi (Bastian 2006). Secara umum, kinerja merupakan prestasi yang dicapai oleh organisasi dalam periode tertentu.

Pemberdayaan lembaga perkreditan merupakan aset yang sangat berharga dan merupakan modal nonfisik yang sngat penting dalam jalannya suatu unit bisnis. Pemberdayaan lembaga perkreditan dapat diartikan sebagai nilai ekonomi dari SDM yang terkait dengan kemampuan, pengetahuan, ide-ide, inovasi, energi dan komitmennya. Pemberdayaan lembaga perkreditan merupakan suatu kemampuan manusia secara pribadi yang merupakan nilai lebih dari manusia itu sendiri. Stewart et.al (2010) dalam Sawarjuwono (2003) mengatakan bahwa pemberdayaan lembaga perkreditan yang disebut juga sebagai modal manusia merupakan lifeblood dalam modal intelektual, sumber dari innovation dan improvement, tetapi merupakan komponen yang sulit untuk diukur.

Pemberdayaan lembaga perkreditan meliputi beberapa kemampuan atau skill yang dimiliki oleh sesorang. Kemampuan-kemampuan tersebut merupakan sesuatu nilai lebih yang dimiliki oleh manusia, kemapuan-kemampuan itulah yang menjadikan manusia berbeda antara manusia yang satu dengan manusia yang lain. Kemampuan-kemapuan tersebut merupakan sesuatu hal yang didapatkan dengan cara mengasah dan melatih kemampuan dan potensi yang dimiliki sesorang.

Coleman (2010) mendefinisikan sumber pendanaan sebagai kemampuan masyarakat untuk bekerja sama, demi mencapai tujuan-tujuan bersama, di dalam berbagai kelompok dan organisasi. Dengan kata lain, sumber pendanaan merupakan suatu kekuatan sosial sebuah masyarakat yang tumbuh dan berkembang dari sebuah keadaan sosial masyarakat suatu tempat dengan mengedepankan asas kekeluargaan guna mencapai tujuan. Putnam dalam Budi (2005) merumuskan bahwa: "Sumber pendanaan (social capital) menunjuk pada ciri-ciri organisasi sosial yang berbentuk jaringan-jaringan horisontal yang di dalamnya berisi norma-norma yang memfasilitasi koordinasi, kerja sama, dan saling mengendalikan yang manfaatnya bisa dirasakan bersama anggotaanggota organisasi”.

Dalam kemajuan sektor UMKM pun sumber pendanaan juga merupakan faktor penentu kemajuan kinerja suatu UMKM. hal tersebut dapat dilihat dari beberapa penelitian yang telah dilakukan menganai peran sumber pendanaan dalam kemajuan kinerja suatu UMKM. Tri Rahmawati dan Hikmah (2010) melakukan penelitian terhadap faktor-faktor yang mempengaruhi kinerja UMKM di Kota Semarang. Hasil dari penelitian tersebut menunjukan, jejaring sosial menjadi salah satu faktor utama disamping faktor-faktor yang lain yang berpengaruh terhadap kinerja UMKM di Kota Semarang. Stam et.al (2013) dalam studi literaturnya melakukan penelitian dengan teknik meta analisis untuk mengathui pengaruh sumber pendanaan terhadap kinerja UMKM. hasil dari penelitian tersebut menunjukan, sumber pendanaan berperan secara signifikan terhadap kinerja UMKM.

Selain penelitian di atas, Kushnirovich (2010) juga melakukan penelitian terhadap para pelaku usaha UMKM di Israel untuk mengetahui apakah sumber pendanaan berpengaruh terhadap kinerja keuangan perusahaan. Hasil dari penelitian tersebut diperoleh bahwa sumber pendanaan berpengaruh terhadap kinerja keuangan perusahaan. Rante (2010) melakukan penelitian mengenai pengaruh budaya etnis dan perilaku kewirausahaan terhadap kinerja UMKM Agribisnis di Provinsi Papua dan hasil dari penelitian tersebut 
menunjukan bahwa semua variabel termasuk budaya etnis berpangaruh positif dan signifikan terhadap kinerja UMKM agribisnis di papua. Hal tersebut menunjukan bahwa, budaya yang merupakan akar dari sumber pendanaan mempunyai peran yang cukup signifikan terhadap kinerja suatu unit bisnis.

\section{METODOLOGI}

Penelitian ini termasuk ke dalam penelitian kuantitatif. Populasi penelitian ini adalah semua pelaku UMKM di Kota Bandar Lampung sebanyak 3.543 UMKM dan jumlah sampel sebanyak 97 UMKM. Analisis dalam penelitian ini menggunakan analisis regresi linier berganda. Untuk mengetahui pengaruh Variabel X terhadap Y baik secara sendiri-sendiri maupun secara bersama-sama digunakan analisis regresi linear berganda, dengan menggunakan Pengolahan data secara Komputer dengan Program SPSS dengan rumus sebagai berikut:

$Y=\alpha+\beta_{1} X_{1}+\beta_{2} X_{2}+E_{t}$

Keterangan:

$\mathrm{Y}=$ Variabel terikat (manajemen strategi Usaha Mikro Kecil Menengah

$\mathrm{X}_{1} \quad=$ Variabel bebas 1 (pemberdayaan lembaga perkreditan)

$\mathrm{X}_{2}=$ Variabel bebas 2 (sumber pendanaan)

$\alpha \quad=$ Intercept

$\beta \quad=$ Koefisien regresi

$\mathrm{E}_{\mathrm{t}} \quad=$ Kesalahan penggunaan (error term)

\section{HASIL DAN PEMBAHASAN}

Berdasarkan hasil penelitian dan pengolahan data maka diperoleh data analisis regresi linier berganda sebagai berikut:

\section{Tabel 3. Analisis Regresi Berganda}

Coefficients $^{a}$

\begin{tabular}{|c|c|c|c|c|c|c|}
\hline \multirow{2}{*}{\multicolumn{2}{|c|}{ Model }} & \multicolumn{2}{|c|}{$\begin{array}{l}\text { Unstandardized } \\
\text { Coefficients }\end{array}$} & \multirow{2}{*}{$\begin{array}{c}\text { Standardized } \\
\text { Coefficients } \\
\text { Beta }\end{array}$} & \multirow[b]{2}{*}{$\mathrm{t}$} & \multirow[b]{2}{*}{ Sig. } \\
\hline & & $\mathrm{B}$ & Std. Error & & & \\
\hline & (Constant) & 10,822 &, 994 & & 20,827 & ,014 \\
\hline & $\begin{array}{l}\text { Pemberdayaan lembaga } \\
\text { perkreditan }\end{array}$ &, 175 & ,076 & ,712 & 15,472 & ,000 \\
\hline & Sumber pendanaan & ,428 &, 078 & ,252 & 5,469 &, 000 \\
\hline
\end{tabular}

a. Dependent Variable: Manajemen strategi

Sumber: Data diolah pada tahun 2021

Berdasarkan tabel di atas, kemudian dimasukkan dalam persamaan:

$\mathrm{Y}=10,822+0,175 \mathrm{X}_{1}+0,428 \mathrm{X}_{2}$

Berdasarkan persamaan tersebut diketahui bahwa"

1. Nilai konstan sebesar 10,822 menunjukkan bahwa nilai manajemen strategi akan bernilai sebesar 10,822 jika variabel pemberdayaan lembaga perkreditan dan sumber pendanaan tetap.

2. Setiap terjadi peningkatan nilai pada variabel pemberdayaan lembaga perkreditan sebesar satu satuan maka manajemen strategi akan meningkat 0,175 satuan.

3. Setiap terjadi peningkatan nilai pada variabel sumber pendanaan sebesar satu satuan, maka manajemen strategi akan meningkat 0,428 satuan.

Berdasarkan keterangan di atas dapat ditarik kesimpulan bahwa nilai koefisien regresi sumber pendanaan lebih besar dari pemberdayaan lembaga perkreditan terhadap manajemen strategi Usaha Mikro Kecil Menengah (UMKM) di Kota Bandar Lampung. 
Koefisien determinasi bertujuan untuk mengukur seberapa jauh kemampuan model dalam menerangkan variasi variabel dependen. Nilai koefisien determinasi adalah $0<\mathrm{R}^{2}<1$. Koefisien determinasi yang mendekati satu berarti variabel-variabel independen memberikan hampir semua informasi yang dibutuhkan untuk memprediksi variabel dependen. Penggunaan $R$ square adalah bias terhadap jumlah variabel independen yang dimasukkan ke dalam model. Setiap tambahan variabel independen ke dalam model, maka $R$ square pasti meningkat tidak peduli apakah variabel independen tersebut berpengaruh secara signifikan atau tidak. Tidak seperti $R$ square, nilai adjusted $R$ square dapat naik atau turun apabila terdapat tambahan variabel independen ke dalam model (Sugiyono, 2011).

Tabel 4. Koefisien Determinasi Pengaruh Pemberdayaan lembaga perkreditan dan Sumber pendanaan Terhadap Manajemen strategi Konsumen Usaha Mikro Kecil Menengah (UMKM) di Kota Bandar Lampung Model Summary

\begin{tabular}{|l|r|r|r|r|}
\hline Model & $\mathrm{R}$ & $\mathrm{R}$ Square & Adjusted R Square & $\begin{array}{c}\text { Std. Error of the } \\
\text { Estimate }\end{array}$ \\
\hline 1 &, $881^{\mathrm{a}}$ &, 777 &, 774 & 1,65996 \\
\hline
\end{tabular}

a. Predictors: (Constant), Sumber pendanaan, Pemberdayaan lembaga perkreditan

Sumber: Data diolah pada tahun 2021

Berdasarkan tabel 4 diketahui bahwa nilai $\mathrm{R}^{2}=0,777 \times 100 \%=77,7 \%$ yang artinya besarnya pengaruh pemberdayaan lembaga perkreditan dan sumber pendanaan terhadap manajemen strategi Usaha Mikro Kecil Menengah (UMKM) di Kota Bandar Lampung adalah sebesar $77,7 \%$ sedangkan selebihnya sebanyak $22,3 \%$ dipengaruhi oleh faktor lain yang tidak dikaji dalam penelitian ini.

Uji t digunakan untuk menunjukkan apakah suatu variabel independen secara individual mempengaruhi variabel dependen (Sugiyono, 2011). Hipotesis yang dipakai adalah:

$\mathrm{H} 0$ : $\mathrm{bi}=0$, artinya suatu variabel independen tidak berpengaruh terhadap variabel dependen. Ha: bi> 0, artinya suatu variabel independen berpengaruh positif terhadap variabel dependen. Kriteria pengujian dengan tingkat signifikansi $(\alpha)=0,05$ ditentukan sebagai berikut:

Apabila $t_{\text {hitung }}>t_{\text {tabel }}$, maka $\mathrm{HO}$ ditolak dan Ha diterima.

Apabila $\mathrm{t}_{\text {hitung }}<\mathrm{t}_{\text {tabel}}$, maka $\mathrm{H} 0$ diterima dan Ha ditolak.

Berdasarkan hasil penelitian dan pengolahan data maka diperoleh:

\section{Tabel 5. Uji t}

\begin{tabular}{|c|c|c|c|c|c|}
\hline \multirow[b]{2}{*}{ Model } & \multicolumn{2}{|c|}{$\begin{array}{l}\text { Unstandardized } \\
\text { Coefficients }\end{array}$} & \multirow{2}{*}{$\begin{array}{c}\text { Standardized } \\
\text { Coefficients } \\
\text { Beta }\end{array}$} & \multirow[b]{2}{*}{$\mathrm{t}$} & \multirow[b]{2}{*}{ Sig. } \\
\hline & $\mathrm{B}$ & Std. Error & & & \\
\hline $1 \quad$ (Constant) & 10,822 & ,994 & & 20,827 & ,014 \\
\hline $\begin{array}{l}\text { Pemberdayaan lembaga } \\
\text { perkreditan }\end{array}$ & ,175 & ,076 & ,712 & 15,472 & ,000 \\
\hline Sumber pendanaan & , 428 & ,078 & ,252 & 5,469 &, 000 \\
\hline
\end{tabular}

a. Dependent Variable: Manajemen strategi

Sumber: Data diolah pada tahun 2021

Berdasarkan tabel 5 diketahui bahwa:

1. Hasil uji $t_{\text {hitung }}$ untuk variabel pemberdayaan lembaga perkreditan sebesar $15,472\left(t_{\text {hitung }}=\right.$ $\left.15,472>t_{\text {tabel }}=1,974\right)$ yang berarti bahwa ada pengaruh pemberdayaan lembaga perkreditan terhadap manajemen strategi Usaha Mikro Kecil Menengah (UMKM) di Kota Bandar Lampung.

2. Hasil uji $t_{\text {hitung }}$ untuk variabel sumber pendanaan sebesar 5,469 ( $t_{\text {hitung }}=5,469>t_{\text {tabel }}$ $=1,974$ ) yang berarti bahwa ada pengaruh sumber pendanaan terhadap manajemen strategi Usaha Mikro Kecil Menengah (UMKM) di Kota Bandar Lampung. 
Uji F bertujuan untuk menunjukkan apakah semua variabel independen yang dimasukkan ke dalam model secara simultan atau bersama-sama mempunyai pengaruh terhadap variabel dependen (Sugiyono, 2011).

a. Membuat hipotesis untuk kasus pengujian F-test di atas, yaitu:

Ho: Tidak ada pengaruh signifikan dari variabel independen yaitu pemberdayaan lembaga perkreditan $\left(\mathrm{X}_{1}\right)$ dan sumber pendanaan $\left(\mathrm{X}_{2}\right)$ secara simultan terhadap variabel dependen yaitu manajemen strategi (Y).

Ha: Ada pengaruh signifikan dari variabel independen yaitu yaitu pemberdayaan lembaga perkreditan $\left(\mathrm{X}_{1}\right)$ dan sumber pendanaan $\left(\mathrm{X}_{2}\right)$ secara simultan terhadap variabel dependen yaitu manajemen strategi (Y).

b. Menentukan $\mathrm{F}$ tabel dan $\mathrm{F}$ hitung dengan tingkat sumber pendanaan sebesar $95 \%$ atau taraf signifikansi sebesar 5\%, maka:

Jika $\mathrm{F}$ hitung > F tabel, maka $\mathrm{H} 0$ ditolak, berarti masing-masing variabel bebas secara bersama-sama mempunyai pengaruh yang signifikan terhadap variabel terikat. Jika $\mathrm{F}$ hitung < $\mathrm{F}$ tabel, maka H0 diterima, berarti masing-masing variabel bebas secara bersama-sama tidak mempunyai pengaruh yang signifikan terhadap variabel terikat.

Tabel 6. Uji F

ANOVA $^{\mathrm{b}}$

\begin{tabular}{|ll|r|r|r|r|r|}
\hline Model & Sum of Squares & df & Mean Square & F & Sig. \\
\hline 1 & Regression & 1505,836 & 2 & 752,918 & 73,246 &, $014^{\mathrm{a}}$ \\
& Residual & 432,607 & 94 & 2,755 & & \\
& Total & 1938,444 & 96 & & & \\
\hline
\end{tabular}

a. Predictors: (Constant), Sumber pendanaan , Pemberdayaan lembaga perkreditan

b. Dependent Variable: Manajemen strategi

Sumber: Data diolah pada tahun 2021

Berdasarkan hasil uji $\mathrm{F}$ di atas, diperoleh $\mathrm{F}_{\text {hitung }}=73,246>\mathrm{F}_{\text {tabel }}=3,05$ dengan signifikansi sebesar 0,014 $(<\alpha=0,05)$ yang berarti bahwa ada pengaruh pemberdayaan lembaga perkreditan dan sumber pendanaan terhadap manajemen strategi Usaha Mikro Kecil Menengah (UMKM) di Kota Bandar Lampung.

Berdasarkan hasil uji $t_{\text {hitung }}$ untuk variabel pemberdayaan lembaga perkreditan sebesar 15,472 $\left(\mathrm{t}_{\text {hitung }}=15,472>\mathrm{t}_{\text {tabel }}=1,974\right)$ yang berarti bahwa ada pengaruh pemberdayaan lembaga perkreditan terhadap manajemen strategi Usaha Mikro Kecil Menengah (UMKM) di Kota Bandar Lampung. Pemberdayaan lembaga perkreditan meliputi beberapa kemampuan atau skill yang dimiliki oleh sesorang. Kemampuan-kemampuan tersebut merupakan sesuatu nilai lebih yang dimiliki oleh manusia, kemapuan-kemampuan itulah yang menjadikan manusia berbeda antara manusia yang satu dengan manusia yang lain. Kemampuan-kemapuan tersebut merupakan sesuatu hal yang didapatkan dengan cara mengasah dan melatih kemampuan dan potensi yang dimiliki sesorang. Dalam perkembangan ilmu pengetahuan, pemberdayaan lembaga perkreditan terdiri atas empat hal: kemampuan, perilaku, usaha, dan waktu, yang semua ini dimiliki dan dikendalikan sendiri oleh karyawan.

Berdasarkan hasil uji $t_{\text {hitung }}$ untuk variabel sumber pendanaan sebesar 5,469 $\left(\mathrm{t}_{\text {hitung }}=5,469>\right.$ $\mathrm{t}_{\text {tabel }}=1,974$ ) yang berarti bahwa ada pengaruh sumber pendanaan terhadap manajemen strategi Usaha Mikro Kecil Menengah (UMKM) di Kota Bandar Lampung. Coleman (2010) mendefinisikan sumber pendanaan sebagai kemampuan masyarakat untuk bekerja sama, demi mencapai tujuan-tujuan bersama, di dalam berbagai kelompok dan organisasi. Dengan kata lain, sumber pendanaan merupakan suatu kekuatan sosial sebuah 
masyarakat yang tumbuh dan berkembang dari sebuah keadaan sosial masyarakat suatu tempat dengan mengedepankan asas kekeluargaan guna mencapai tujuan. Putnam dalam Budi (2005) merumuskan bahwa: "Sumber pendanaan (social capital) menunjuk pada ciri-ciri organisasi sosial yang berbentuk jaringan-jaringan horisontal yang di dalamnya berisi norma-norma yang memfasilitasi koordinasi, kerja sama, dan saling mengendalikan yang manfaatnya bisa dirasakan bersama anggota-anggota organisasi”.

Sumber pendanaan juga dapat diartikan sebagai kemampuan masyarakat dalam menjalin kerjasama satu sama lain dengan berdasarkan atas kesamaan-kesamaan tertentu sehingga terjadi sebuah ikatan khusus selanjutnya menjadi kekuatan penting dalam ekonomi dan aspek eksistensi sosial lainnya. Bourdieu dalam Winter (2000) menjelaskan bahwa sumber pendanaan (social capital) merupakan wujud nyata dari suatu institusi kelompok yang merupakan jaringan koneksi yang bersifat dinamis dan bukan alami. Jika sebuah keterikatan dalam suatu komunitas tertentu sudah terjadi, maka sumber pendanaan juga akan terbentuk sedemikian rupa sehingga dampaknya akan memberikan manfaat yang positif dalamsegala bidang.

\section{KESIMPULAN}

Berdasarkan hasil penelitian dan pembahasan, maka dapat diambil kesimpulan bahwa

a. Ada pengaruh pemberdayaan lembaga perkreditan terhadap manajemen strategi Usaha Mikro Kecil Menengah (UMKM) di Kota Bandar Lampung

b. Ada pengaruh sumber pendanaan terhadap manajemen strategi Usaha Mikro Kecil Menengah (UMKM) di Kota Bandar Lampung

c. Ada pengaruh pemberdayaan lembaga perkreditan dan sumber pendanaan terhadap manajemen strategi Usaha Mikro Kecil Menengah (UMKM) di Kota Bandar Lampung

Berdasarkan kesimpulan, maka saran yang dapat diberikan peneliti adalah:

a. Diharapkan bagi UMKM di Bandar Lampung menggunakan kompetensi SDM dalam meningkatkan manajemen strategi UMKM di Bandar Lampung dengan cara mengalokasikan SDM ke dalam hal-hal sesuai dengan kemampuan dan keahliannya sehingga manajemen strategi UMKM di Bandar Lampung akan semakin meningkat, terutama dalam hal usaha memberikan penghargaan kepada para karyawan yang manajemen strateginya selalu meningkat, agar karyawan selalu bersemangat kerja.

b. Diharapkan UMKM di Bandar Lampung menggunakan sumber modal sosial yang ada untuk meningkatkan manajemen strateginya, karena dengan adanya sumber modal sosial yang memadai akan menunjang manajemen strategi UMKM di Bandar Lampung, terutama mengenai usaha yang selalu mengutamakan kepentingan umum dalam melakukan bisnis.

c. Diharapkan kepada UMKM di Bandar Lampung untuk meningkatkan modal finansialnya baik modal sendiri maupun modal yang didapatkan dari pinjaman pihak ketiga, dalam rangka meningkatkan UMKM di Bandar Lampung, terutama mengenai perlengkapan usaha dapat memenuhi mendukung hasil usaha.

d. Diharapkan manajemen strategi UMKM Kuliner dapat lebh ditingkatkan melalui peningkatan kompetensi SDM, modal sosial dan modal finansialnya yang optimal dalam peningkatan manajemen strategi UMKM di Bandar Lampung, terutama mengenai bakat dan sifat pribadi karyawan akan mempengaruhi manajemen strategi UMKM yang masih kurang dan modal finansial yang masih kurang baik dalam meningkat manajemen strategi UMKM. 


\section{DAFTAR PUSTAKA}

Abdulllah, M, 2015, Metodologi Penelitian Kuantitatif . Yogyakarta: Aswaja Pressindo.

Abdolmohammadi, M.J, 2005, Intellectual Capital Disclousure and Market Capitalization. Jornal of Intellectual Capital. Vol. 6 No. 3. pp.397-416

Ardiana, 2010, Kompetensi SDM UKM dan Pengaruhnya Terhadap KInerja UKM di Surabaya. Jurnal Manajemen dan Kewirausahaan, VOL. 12, No. 1, hlm:42-55.

Bustami, Bastian \& Nurlela. 2009. Akuntansi Biaya Edisi Pertama. Mitra Wacana Media: Jakarta.

Brealey et.al, 2008, Dasar-dasar Manajemen Keuangan Perusahaan Edisi 5. Jakarta: Erlangga

Brigham, F. Eugne dan Joel F. Houston, 2001, Manajemen Keuangan Edisi Delapan. Jakarta: Erlangga.

Chittithaworn et.al, 2011, Faktor-faktor yang mempengaruhi kesuksesan UMKM di Thailand, Jurnal Penelitian

Chaundry, S, 2010, Working Paper: Hidden attributes of human resources for succesful innovation.

Demirbag, M, 2006, An Analysis of the relationship between TQM Implementation and Organizational Performance: Evidence from Turkish SMes. Journal of Manufacturing Technology Management, Vol. 17 No. 6, pp. 829-47.

Sondari, Dewi, d, n.d., Analisis Faktor yang Mempengaruhi Inovasi Produk Nanokapsulasi Ekstrak Pegagan sebagai Sediaan untuk Mengatasi Selulit. jurnal Teknik Industri ISSN: 1411-6340.

Edvinsson, L. and M. Malone. 1997. Intellectual Capital: Realizing Your Company's True value by Finding Its Hidden Brainpower. HarperCollins, New York, NY.

Fanbasten, N, 2014, Enhancing Business Performance Through Learning Organization and Knowing Sharing Capability: The Mediation Effect of Innovation Capability Using PLS Method. Journal The Winner, Vol. 15 No.2 95-107.

Purnomo, Agus. 2011. Pengaruh Brand Equity Terhadap Loyalitas Konsumen Produk Air Minum Dalam Kemasan (AMDK) Merk Aqua Di Bandar Lampung, Jurnal Sosialita, Vol.1 Issue 2. 